\section{Uniconazole Suppresses Bypass Shoot Development and Alters Flowering of Two Forcing Azalea Cultivars}

\author{
Gary J. Keever and William J. Foster ${ }^{1}$ \\ Department of Horticulture and Alabama Agricultural Experiment \\ Station, Auburn University, AL 36849 \\ Additional index words. Rhododendron $\times$ sp., growth retardant, XE-1019, PP333, \\ paclobutrazol, daminozide, Sumagic, Bonzi, B-Nine
}

\begin{abstract}
Redwings' and 'Gloria' azaleas (Rhododendron $\times$ 'Redwings' and 'Gloria') were treated with foliar sprays of uniconazole, paclobutrazol, or daminozide to suppress bypass shoot development and promote flower initiation and development. Uniconazole at 5 and $25 \mathrm{mg} \cdot \mathrm{liter}^{-1}$ suppressed bypass shoot development of 'Redwings' and 'Gloria', respectively. Flowering of 'Gloria', but not 'Redwings', was delayed slightly

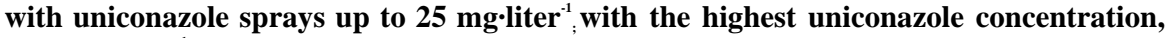
$200 \mathrm{mg} \cdot$ liter $^{-1}$, flowering was delayed as much as $\mathbf{1 8}$ days. Flower count of 'Gloria' was not affected by lower concentrations of uniconazole, but it was greatly reduced in both cultivars with concentrations above $75 \mathrm{mg}^{-1 i t e r}{ }^{-1}$. Uniconazole was more active than paclobutrazol sprays of similar concentrations or than two daminozide sprays of $3000 \mathrm{mg} \cdot$ liter $^{-1}$. Chemical names used: (E)-1-(p-chlorophenyl)-4,4-dimethyl-2-(1,2,4-triazol-1-yl)-1-penten-3-ol (uniconazole); (2RS,3RS)-1-(4-chlorophenyl)-2-(1,1-dimethylethyl)-(1H1,2,4,-triazol-l-yl-)pentan-3-ol (paclobutrazol); butanedioic acid mono(2,2-dimethylhydrazide (daminozide),
\end{abstract}

Growth retardants are commonly applied to forcing azaleas to suppress internode elongation (Stuart, 1961), promote flower bud initiation and development (Criley, 1969), and inhibit the growth of vegetative shoots

Received for publication 17 Aug. 1990. Appreciation is extended to Blackwell Nurseries, Semmes, Ala., for donation of plant material; John McGuire for his assistance with statistics; and Cathy Browne for her technical assistance. The cost of publishing this paper was defrayed in part by the payment of page charges. Under postal regulations, this paper therefore must be hereby marked advertisement solely to indicate this fact.

${ }^{1}$ Former Superintendent, Ornamental Horticulture Substation, Mobile, Ala. Present address: GraceSierra, 1001 Yosemite Dr., Milpitas, CA 95035. that develop basipetally to flower buds (bypass shoots) (Keever and Foster, 1989; Whealy et al., 1988). Daminozide (B-Nine) and chlormequat chloride (Cycocel) are the principal growth retardants applied to forcing azaleas; however, delayed flowering, smaller flowers (Yoder Brothers, 1969), and greater bypass shoot development (Keever and Foster, 1989) are undesirable side effects of daminozide, while delayed flowering and smaller plants occur with chlormequat chloride (Larson, 1975). Triazole inhibitors, a group of plant bioregulants represented by paclobutrazol (Bonzi) and uniconazole (Sumagic), have growth-retardant activity on a wide range of crop species (Davis et al., 1988). Paclobutrazol sprays of 150 and 200 $\mathrm{mg} \cdot$ liter $^{-1}$ controlled bypass shoot development, increased flower count and size, and decreased forcing time of forcing azaleas when compared to daminozide (Keever and Foster, 1989). The objective of this study was to determine the effects of uniconazole on bypass shoot development and flowering of forcing azaleas relative to daminozide and paclobutrazol.

Uniform 9.0-cm-tall liners of 'Redwings' and 'Gloria' azaleas were potted 16 Dec. 1988 into 3.7-liter azalea pots using 3 sphagnum peat :2 softwood shavings (v/v) growth medium amended with $3.6 \mathrm{~kg} \cdot \mathrm{m}^{-3} \mathrm{SREF} 19 \mathrm{~N}-$ 1P-8.3K (O.M. Scott \& Sons, Marysville, Ohio), $3.6 \mathrm{~kg} \cdot \mathrm{m}^{-3}$ dolomitic limestone, and $0.4 \mathrm{~kg} \cdot \mathrm{m}^{-3}$ Micromax micronutrient fertilizer (Grace-Sierra, Milpitas, Calif. ). Plants were placed in a double polyethylene greenhouse in a commercial azalea nursery in Semmes, Ala., and maintained according to common commercial practices. Plants were sheared on 22 Mar. and 25 June 1989; 1 day after each shearing, plants were sprayed with 2,3:4,6-bis-O-(1-methylethylidene)- $\alpha$-L-xylo2-hexulofuranosonic acid (dikegulac) (PBI/Gordon Corp., Kansas City, Mo.) at 3627 $\mathrm{mg} \cdot$ liter ${ }^{-1}$ in 0.2 liter $\cdot \mathrm{m}^{-2}$ to increase lateral branching. Plants were transferred to an outdoor shade structure (47\% light exclusion) on 20 July and topdressed with $12 \mathrm{~g} 18 \mathrm{~N}-$ $2.2 \mathrm{P}-8.3 \mathrm{~K} /$ pot (Woodace Topdress Special, Vigoro Industries, Fairview Heights, Ill.) on 25 July. When the following treatments were applied on $15 \mathrm{Sept}$. at $204 \mathrm{ml} \cdot \mathrm{m}^{-2}$ flower buds were developing on most shoots but no bypass shoots were present: single uniconazole sprays of $0,5,10,15,25,50,75$, 100,150 , or $200 \mathrm{mg} \cdot \mathrm{liter}^{-1}$; single paclobutrazol sprays of $150 \mathrm{or} 200 \mathrm{mg} \cdot \mathrm{liter}^{-1}$; and a daminozide spray of $3000 \mathrm{mg} \cdot \mathrm{liter}^{-1}$, which was repeated 1 week later. Sprays were applied using a hand-held sprayer to uniformly wet foliage and stems. Temperature was $28 \mathrm{C}$ with $69 \%$ relative humidity and clear skies at the time of the first application. Conditions were clear and at $25 \mathrm{C}$ with $75 \%$ rela- 
Table 1. Plant growth retardant effects on bypass shoot and flower development of Rhododendron $\times$ 'Gloria'.

\begin{tabular}{|c|c|c|c|c|c|c|}
\hline \multicolumn{2}{|c|}{ Treatment } & \multicolumn{2}{|c|}{ Bypass shoots } & \multirow{2}{*}{$\begin{array}{l}\text { Time to open } \\
\text { flowers }{ }^{y} \\
\text { (days) }\end{array}$} & \multicolumn{2}{|c|}{ Flower } \\
\hline $\begin{array}{l}\text { Growth } \\
\text { retardant }\end{array}$ & $\underset{\left(\mathrm{mg} \cdot \text { liter }^{-1}\right)}{\text { Concn }}$ & No. & $\begin{array}{l}\text { Length }^{2} \\
\text { (cm) }\end{array}$ & & No. & $\begin{array}{l}\operatorname{Diam}^{x} \\
(\mathrm{~cm})\end{array}$ \\
\hline Control & 0 & 2.0 & 4.9 & 37 & 315 & 6.8 \\
\hline Uniconazole & 5 & 2.1 & 3.0 & 41 & 359 & 6.7 \\
\hline & 10 & 3.1 & 1.8 & 40 & 307 & 7.0 \\
\hline & 15 & 2.0 & 1.8 & 42 & 323 & 6.9 \\
\hline & 25 & 0.7 & 1.4 & 44 & 336 & 6.7 \\
\hline & 50 & 1.3 & 1.7 & 46 & 333 & 7.2 \\
\hline & 75 & 0.0 & $\ldots$ & 47 & 347 & 6.6 \\
\hline & 100 & 0.0 & -.- & 49 & 283 & 7.2 \\
\hline & 150 & 0.0 & ... & 49 & 215 & 7.1 \\
\hline & 200 & 0.0 & $\ldots$ & 55 & 142 & 7.0 \\
\hline $\begin{array}{l}\text { Significance } \\
\text { of rate }\end{array}$ & & $Q$ & $Q$ & C & $\mathrm{C}$ & NS \\
\hline Paclobutrazol & 150 & 1.0 & 3.2 & 39 & 332 & 6.8 \\
\hline & 200 & 1.9 & 2.8 & 41 & 338 & 7.1 \\
\hline Daminozide & 3000 & 7.4 & 3.6 & 45 & 312 & 7.1 \\
\hline LSD $^{v}$ & & 3.5 & 1.6 & 4.6 & 59 & $\mathrm{NS}^{u}$ \\
\hline
\end{tabular}

${ }^{2}$ Mean length of three longest bypass shoots on each plant.

'Days to full bloom beginning when plants moved from cooler to greenhouse and determined when $75 \%$ of flowers were fully open.

${ }^{\mathrm{x}}$ Mean of three randomly selected blooms per plant.

"Significance of regression analysis at $P=0.05: \mathrm{Q}=$ quadratic, $\mathrm{C}=$ cubic, NS $=$ nonsignificant. Control included in regression analysis.

'Mean separation within columns by a pooled protected Fisher's least significant test, $P=0.05$; LSD used for making comparisons of interest within columns.

"F value not significant.

Table 2. Plant growth retardant effects on bypass shoot and flower development of Rhododendron $\mathrm{x}$ 'Redwings'.

\begin{tabular}{|c|c|c|c|c|c|c|}
\hline \multicolumn{2}{|c|}{ Treatment } & \multicolumn{2}{|c|}{ Bypass shoots } & \multirow{2}{*}{$\begin{array}{l}\text { Time to open } \\
\text { flowers } \\
\text { (days) }\end{array}$} & \multicolumn{2}{|c|}{ Flower } \\
\hline $\begin{array}{l}\text { Growth } \\
\text { retardant }\end{array}$ & $\begin{array}{c}\text { Concn } \\
\left(\mathrm{mg} \cdot \text { liter }^{-1}\right)\end{array}$ & No. & $\begin{array}{l}\text { Length }^{x} \\
(\mathrm{~cm})\end{array}$ & & No. & $\begin{array}{r}\operatorname{Diam}^{x} \\
(\mathrm{~cm}) \\
\end{array}$ \\
\hline Control & 0 & 5.5 & 3.5 & 46 & 267 & 6.9 \\
\hline \multirow[t]{9}{*}{ Uniconazole } & 5 & 3.0 & 2.5 & 44 & 274 & 7.3 \\
\hline & 10 & 2.8 & 2.8 & 45 & 275 & 7.4 \\
\hline & 15 & 2.5 & 1.7 & 46 & 268 & 7.2 \\
\hline & 25 & 2.1 & 1.6 & 48 & 268 & 7.1 \\
\hline & 50 & 1.8 & 1.1 & 53 & 273 & 7.2 \\
\hline & 75 & 0.5 & 1.0 & 56 & 249 & 7.5 \\
\hline & 100 & 0.0 & $\cdots$ & 60 & 215 & 7.5 \\
\hline & 150 & 0.0 & --- & 60 & 158 & 7.1 \\
\hline & 200 & 0.0 & --- & 63 & 148 & 7.3 \\
\hline $\begin{array}{c}\text { Significance } \\
\text { of rate }\end{array}$ & & $\mathrm{C}$ & $Q$ & $\mathrm{C}$ & $\mathrm{C}$ & NS \\
\hline \multirow[t]{2}{*}{ Paclobutrazol } & 150 & 3.6 & 2.8 & 44 & 311 & 7.3 \\
\hline & 200 & 4.5 & 2.7 & 46 & 260 & 6.9 \\
\hline Daminozide & 3000 & 4.4 & 3.1 & 46 & 260 & 7.3 \\
\hline LSD $^{v}$ & & 3.4 & 1.1 & 3.9 & 46 & 0.4 \\
\hline
\end{tabular}

${ }^{2}$ Mean length of three longest bypass shoots on each plant.

${ }^{y}$ Days to full bloom beginning when plants moved from cooler to greenhouse and determined when $75 \%$ of flowers were fully open.

${ }^{x}$ Mean of three randomly selected blooms per plant.

"Significance of regression analysis at $P=0.05: \mathrm{Q}=$ quadratic, $\mathrm{C}=$ cubic, $\mathrm{NS}=$ nonsignificant. Control included in regression analysis.

"Mean separation within columns by a pooled protected Fisher's least significant test, $P=0.05$; LSD used for making comparisons of interest within columns.

tive humidity when the second daminozide application was made. There were four replicates of two plants, each completely randomized within a cultivar.

Plants were sprayed with a benomylchlorothalonil mixture $(2 \mathrm{ml}$ each/liter $)$ on 1 Nov. and subsequently held in darkness at 4C for 6 weeks. Plants were removed from the cooler on $13 \mathrm{Dec}$. and forced into flower in an unshaded double polyethylene greenhouse with 20/18C (day/night) minima. Time until flowering was determined from the time plants were removed from the cooler until uniconazole increased (Tables 1 and 2). At concentrations higher than $50 \mathrm{mg} \cdot$ liter $^{-1}$ essentially no bypass shoots developed on either cultivar. Plants treated with paclobutrazol sprays of 150 or $200 \mathrm{mg} \cdot \mathrm{liter}^{-1}$ developed bypass shoot counts and lengths similar to those sprayed with uniconazole at 10 mg.liter ${ }^{-1}$ or less. No bypass shoots formed on either cultivar sprayed with uniconazole at 150 or $200 \mathrm{mg} \cdot$ liter $^{-1}$; these concentrations of paclobutrazol resulted in at least 3.6 bypass shoots per plant on 'Redwings' and 1.0 on 'Gloria'. 'Gloria' sprayed with daminozide grew more bypass shoots than plants sprayed with uniconazole or paclobutrazol, or the control. Bypass shoot counts and lengths of 'Redwings' treated with daminozide were similar to those of paclobutrazoltreated plants and plants sprayed with the lower concentrations of uniconazole.

Days to flower for both cultivars increased cubically with increasing concentrations of uniconazole. The delay in flowering was most pronounced when plants were sprayed with uniconazole concentrations of $50 \mathrm{mg} \cdot$ liter $^{-1}$ or higher. Comparisons of days to flower among growth retardants varied with cultivar. Days to flower were similar when 'Redwings' were sprayed with daminozide, paclobutrazol, or with uniconazole at 25 $\mathrm{mg} \cdot \mathrm{liter}^{-1}$ or less. Time to flower of 'Gloria' was similar for plants treated with daminozide or uniconazole at $150 \mathrm{mg} \cdot$ liter ${ }^{-1}$ or less, but longer than for plants treated with 150 $\mathrm{mg}$ paclobutrazol/liter.

Flower count was minimally affected by the lower concentrations of uniconazole when compared to the control; flower counts of plants treated with uniconazole decreased dramatically at concentrations higher than 75 $\mathrm{mg} \cdot$ liter $^{-1}$. Paclobutrazol or daminozide sprays resulted in similar flower counts as uniconazole sprays of $75 \mathrm{mg} \cdot$ liter $^{-1}$ or less, but in more flowers than the three highest concentrations of uniconazole.

Flower diameter was not affected by increasing concentrations of uniconazole. Flower diameters of plants treated with paclobutrazol or daminozide were similar to each other and to those of uniconazole-treated plants.

Reductions in the number of bypass shoots and length of 'Redwings' occurred with uniconazole at $5 \mathrm{mg} \cdot \operatorname{liter}^{-1} 25$ and $10 \mathrm{mg} \cdot$ liter $^{-1}$ were required to achieve a similar reduction in bypass shoot count and length, respectively, of 'Gloria'. Flowering was minimally delayed with the lower concentrations of uniconazole, but was delayed 1 week or longer with concentrations of $50 \mathrm{mg} \cdot$ liter $^{-1}$ or higher. Flowering, as indicated by flower count and diameter, was not affected by lower concentrations of uniconazole, but flower count was greatly reduced with concentrations higher than $75 \mathrm{mg} \cdot 1$ iter $^{-1}$.

Uniconazole sprays were much more effective in controlling bypass shoot growth than paclobutrazol sprays of similar concentrations or than two daminozide sprays of $3000 \mathrm{mg} \cdot \mathrm{liter}^{-1}$. The greater activity of uniconazole relative to paclobutrazol has been documented with other crops (Bassi et al., 
1986; Davis et al., 1987). Daminozide was the least effective retardant in suppressing bypass shoot development of 'Gloria', but similar in effect to paclobutrazol and the lower concentrations of uniconazole when applied to 'Redwings'.

\section{Literature Cited}

Bassi, P.K., S.M. Abernathy, and D.E. Glazier. 1986. Comparative efficacy of XE-1019D with other plant growth regulators. Proc. Plant Growth Regulat. Soc. Amer. 13:54-61.

Criley, R.A. 1969. Effects of short photoperiods, cycocel, and gibberellic acid upon flower bud initiation and development in azalea 'Hexe'. J. Amer. Soc. Hort. Sci. 94:392-396.

Davis, T.D., H.S, Geholt, C.F. Williams, and N,. Sankhla. 1987. Comparative shoot growth-retarding activities of paclobutrazol and XE-1019. Proc. Plant Growth Regulat. Soc. Amer. 14:12119.4

Davis, T.D., G.L. Steffens, and N. Sankhla. 1988. Triazole plant growth regulators, p. 63-105. In: J. Janick (ed.). Hort. Revs. vol. 10. Timber Press, Portland, Ore.

Keever. G.J. and W.J. Foster. 1989. Response of two florist azalea cultivars to foliar applications of a growth regulator. J. Environ. Hort. 7:5659 .

Larson, R.A. 1975. Continuous production of flowering azaleas, p. 72-77. In: A.M. Kofranek and R.A. Larson (eds.). Growing azaleas commercially, Davis, Calif. Univ. Calif. Div. Agr. Sci. Publ. 4058.

Stuart. N.W. 1961. Initiation of flower buds in rhododendron after application of growth retardants. Science 134:50-52.

Whealy, C.A., T.A. Nell, and J.E. Barrett. 1988. Plant growth regulator reduction of bypass shoot development in azalea. HortScience 23:166-167.

Yoder Brothers. 1969. Yoder azaleas 1970. Growers Circle News 72:3. 